\section{RESOLVING THE RESOURCE NATIONALISM STRUGGLE}

The control of national resources and the challenges for international dispute resolution formed the subject of a conference at Charles Clore House on October 31 attended by members of international law firms and representatives of commercial organisations such as major oil companies, together with Middle East delegates. Organised jointly by the Institute and the IDR Group, the conference was opened by Professor Avrom Sherr, Director of the IALS, and an overview was given by the head of the IDR Group, Anthony Connerty.

The Institute needs no introduction to readers of this journal, but a brief mention should be made of the IDR Group ${ }^{1}$. The Group, a small body of international dispute resolution specialists, was launched in April 2008 at a Reception in the Houses of Parliament where the Attorney General was guest speaker. Membership of the Group is made up of arbitrators, lawyers and other professionals from a number of countries around the world. The experience of the Group reaches into the state level of international dispute resolution - various members have sat as judges and arbitrators in the International Court of Justice (ICJ) and the Permanent Court of Arbitration (PCA) in The Hague, the International Tribunal for the Law of the Sea in Hamburg (ITLOS), and the International Centre for Settlement Disputes in Washington DC (ICSID).

Members also act as advocates and arbitrators worldwide in international arbitrations conducted under the Rules of the major international commercial arbitral institutions. Attached to the Group is a panel of consultants - experts in areas of significance to international dispute resolution such as petroleum, mining and metals.

Members of the Group participating in the conference were Anthony Connerty, Lord Anderson of Swansea, Andrew Berkeley, Professor Munir Maniruzzaman, Rt Hon Donald McKinnon, Judge Thomas Mensah, David Branson, Johan Gernandt and Professor Derek Roebuck. Other speakers were John Hardiman of Sullivan \& Cromwell and John Trenor of Wilmer Hale. The conference was sponsored by Sullivan \& Cromwell and supported by BIICL (British Institute of International and Comparative Law) and OGEL (Oil, Gas \& Energy Law Intelligence).

Divided into three sessions chaired by Lord Anderson, Sir Henry Brooke and Sir Anthony Evans, the conference speakers considered the conference's central theme under three heads:

- The issue of resource nationalism.

- Whether "good offices" can assist in relation to resource nationalism.

- Whether established international dispute resolution bodies have a role to play in resolving disputes between resource-rich countries and consuming countries - can

1 Information on the IDR Group can be seen at www.idrgroup.org

\begin{tabular}{|c|c|}
\hline Articles & \\
\hline Legal services in NW England: the changing landscape & 3 \\
\hline Lawyers and legal services in NW England & 4 \\
\hline $\begin{array}{l}\text { The Legal Services Act - a perspective from the Legal } \\
\text { Services Ombudsman for England and Wales and the }\end{array}$ & \\
\hline Legal Services Complaints Commissioner & 7 \\
\hline Advocacy as an important public service & 11 \\
\hline Legal services: opportunities and challenges & 14 \\
\hline $\begin{array}{l}\text { Law centres and the future of community-based } \\
\text { legal services }\end{array}$ & 17 \\
\hline Institute News & 20 \\
\hline Articles (cont'd) & \\
\hline $\begin{array}{l}\text { Draconian and manifestly unjust: how the confiscation } \\
\text { regime has developed }\end{array}$ & 22 \\
\hline The end of blasphemy law & 25 \\
\hline $\begin{array}{l}\text { Dutch company and partnership law: some proposed } \\
\text { changes }\end{array}$ & 28 \\
\hline
\end{tabular}

these traditional "western" bodies satisfy non-western countries that they will receive a fair and unbiased hearing?

\section{ISSUE OF RESOURCE NATIONALISM}

Resource nationalism is a term which has come into general use in recent years. But it refers to a perennial tension between the sovereign possessors of natural resources and foreign enterprises which, historically at least, had a monopoly of the technical and economic competences efficiently to exploit them. This tension can work constructively, resulting in the formation of national corporations which can enter into long term mutually beneficial partnership with the foreign enterprises and which, in time, develop their own competence. But, sometimes, it manifests itself as conflict. Although resource nationalism is not confined to oil and gas resources, it is the energy industry that plays a prominent role in resource nationalism issues - and oil and gas featured significantly in the conference.

The resource nationalism struggle is seen in fairly stark terms in the efforts of oil-rich producing countries to revise the basis of agreements made with nationals of consuming countries. The issue of resource nationalism raises a number of problems, including state sovereignty, fair compensation in the event of expropriation, stabilisation clauses - and the method of dealing with claims arising as a result of the breach of stabilisation clauses. Resolution of such claims might be by way of litigation in national courts or arbitration under the rules of one of the international commercial arbitral institutions: or by ad hoc arbitration or arbitration under the provisions of an investment treaty such as the 1995 International Convention on the Settlement of Investment Disputes - the ICSID Convention. 
An example was given by Anthony Connerty in his conference overview of a dispute involving (i) a stabilisation clause (ii) expropriation (iii) ICC arbitration (iv) ICSID arbitration and (v) proceedings in a national court. The Mobil Cerro Negro v Petroleos de Venezuela case came before the English High Court in early 2008. The underlying dispute between the parties involved claims by Mobil against Venezuela's state-run oil company, Petroleos de Venezuela. Claims were for breaches of a participation agreement to explore the Cerro Negro oilfield in the Orinoco Belt in Venezuela. The Venezuelan government took control of Mobil's 41.7 per cent stake in the project in accordance with new Venezuelan legislation which "migrated" oil interests held by foreign companies to companies which were at least 60 per cent Venezuelan owned. In response, Mobil commenced an ICC arbitration against Petroleos, in addition to commencing an ICSID arbitration against Venezuela. In January 2008 Mobil obtained a worldwide freezing order in the English courts under section 44 of the Arbitration Act 1996. The order was claimed in support of an ICC arbitration in New York.

On a subsequent successful application by Petroleos to set aside the freezing order, Mr Justice Walker said that it was convenient to refer to the Venezuelan legislation dealing with the "migration" of non-Venezuelan oil interests to companies which were at least 60 per cent Venezuelan owned as the "expropriation legislation". The judge commented on the sums of money involved: the book value of the national oil company of Venezuela was US\$56 billion "in the sense of thousand million. I am not aware of any previous freezing order made by the courts of England and Wales against a company which said that its net assets had a book value of this size." He went on to say that the order which had been made had frozen assets worldwide up to a value of US \$12 billion: "I am not aware of any previous freezing order made by the courts of England and Wales for a total sum of this size."

The type of difficulties which can be raised by resource nationalism was vividly illustrated by Andrew Berkeley in the first of the conference sessions chaired by Lord Anderson of Swansea: "should, or could, a profit sharing agreement made in respect of new discoveries when the price of oil was $\$ 10$ per barrel still apply later, when the developments have been made and the price of oil has increased six or ten fold?"

\section{"GOOD OFFICES" AND RESOURCE NATIONALISM}

Can "good offices" assist in resolving resource nationalism problems? Judge Thomas Mensah, the first President of the International Tribunal for the Law of the Sea in Hamburg, stressed that international law places an obligation on all States to settle their disputes through peaceful means. He gave an example of the use of good offices in relation to a land and maritime border dispute between two States: the Cameroon - Nigeria case. A century-old dispute over the oil-rich Bakassi peninsula and other areas prompted military clashes in the early 1990s between Cameroon and Nigeria. Turning to international law and the UN to prevent further conflict, both sides agreed to abide by a 2002 decision of the International Court of Justice, delineating the 1,600-kilometer land and maritime border between the countries. The United Nations had provided good offices and technical assistance in helping to ensure that the parties peacefully implement the ICJ decision.

\section{ROLE OF ESTABLISHED INTERNATIONAL DISPUTE RESOLUTION BODIES IN RESOURCE NATIONALISM ISSUES}

Sir Anthony Evans, a former judge of the English Court of Appeal who is currently the Chief Justice of the Dubai International Finance Centre Court, chaired the third conference session. This produced some lively debate. While most speakers were of the opinion that established international dispute resolution bodies do have a role to play in dealing with issues of resource nationalism, David Branson adopted a different view. He took Latin and South America as his example: "In 1868, Argentine jurist Carlos Calvo asserted that South America should require foreign investors to adjudicate their disputes in the local courts. The point was simple-foreign courts or "diplomatic protection' favoured powerful nations over weak nations.”

He said that the position in 2008 is that "South American governments have formed UNASUR, a dream to form the South American equivalent of the European Union. They no longer want to submit natural resource decisions to arbitration in ICSID or 'Northern' countries. They want to have decisions made in the region - the resumption of the Calvo doctrine."

\section{FUTURE DEVELOPMENTS IN THE RESOLUTION OF RESOURCE NATIONALISM DISPUTES?}

All three of the conference sessions provoked questions and discussions between speakers and the audience: discussion which is likely to continue given the reemergence of resource nationalism issues in various parts of the world. The overall view of the conference was that the existing international dispute resolution bodies do indeed have a role to play in resolving resource nationalism conflicts. These bodies include both those at the inter-state level, such as the ICJ, PCA, ITLOS and ICSID, and those in the field of international commercial arbitration, such as the International Chamber of Commerce, the London Court of International Arbitration, and the Arbitration Institute of the Stockholm Chamber of Commerce.

The dispute resolution process most discussed was international arbitration: but it was clear from the session chaired by Sir Henry Brooke that good offices can have a significant role to play, particularly in disputes between states. We must wait to see whether other international dispute resolution organisations and other dispute resolution processes will emerge to assist in the resolution of resource nationalism disputes. For example, will the creation of the Union of South American Nations (UNASUR) result in amongst other things the provision of a dispute resolution system catering for Latin and South America?

\section{Anthony Connerty}

Head of the IDR Group 